\title{
Tissue-Specific Expression of Calcium Channels
}

\author{
Roger Hullin, Martin Biel, Veit Flockerzi, and Franz Hofmann
}

The high-voltage-activated calcium channel is a multimeric protein complex containing $\alpha_{1}, \alpha_{2} / \delta, \beta$, and $\gamma$ subunits. The $\alpha_{1}$ subunit is the ion conduction channel and contains the binding sites for calcium channel blockers and toxins. Three genes code for distinct L-type, dihydropyridinesensitive $\alpha_{1}$ subunits; one gene codes for the neuronal P-type (Purkinje) $\alpha_{1}$ subunit; and one gene codes for the neuronal $N$-type $\alpha_{1}$ subunit. The smooth and cardiac muscle L-type calcium channel $\alpha_{1}$ subunits are splice variants of the same gene. The $\alpha_{1}$ subunits are coexpressed with a common $\alpha_{2} / \delta$ subunit and tissue-specific $\beta$ subunits (at least three genes). The $\gamma$ subunit apparently is expressed only in skeletal muscle. The properties of these cloned and expressed calcium channels are discussed here. (Trends Cardiovasc Med 1993;3:48-53)

Calcium entry across the plasma membrane in response to hormonal or electrical stimuli represents a major pathway of cellular control of calcium. The voltagedependent calcium channels, activated and inactivated at a high membrane potential, are the best-characterized plasmalcmmal calcium entry pathway, primarily because of the existence of powerful and specific channel-blocking agents. By the use of the organic calcium channel blockers (CaCBs) originally introduced by Fleckenstein et al. (1967), and several neurotoxins, these channels have been subdivided into three distinct classes, the L-, N-, and P-type calcium channels (Figure 1). In contrast, no specific ligands are presently available to characterizc the T-type calcium channel, which is low voltage activated and present in a wide variety of excitable and nonexcitable cells. L-, N-, and P-type calcium channels are activated at a high

Roger Hullin, Martin Biel, Veit Flockerzi, and Franz Hofmann are at the Institut für Pharmakologie und Toxikologie der Technischen Universität München, Biedersteiner Str. 29, 8000 München 40, Germany. membrane potential (around $-30 \mathrm{mV}$ ), inactivate slowly (long lasting), and are expressed in neuronal and nonneuronal cells (Tsien et al. 1991). N- and P-type calcium channels are blocked specifically by $\omega$-conotoxin GVIA and the funnel web spider toxin $\omega$-Aga-IVA, respectively (Mintz et al. 1992). Both channels have been identified only in neurons and neuroendocrine cells. Ltype channels are readily blocked by the classic CaCBs nifedipine (a 1,4-dihydropyridine, DHP), verapamil (a phonylalkylamine, PAA), and diltiazem (a benzothiazepine) (Glossmann and Striessnig 1988, Hofmann et al. 1990). L-type calcium channels are expressed in neuronal and endocrine cells and in cardiac, smooth, and skeletal muscle. In skeletal muscle, they are essential for excitation-contraction coupling, which does not require calcium influx through the channel. In the normal heart, they are necessary for the generation and propagation of electrical impulses and for the initiation of contraction in atrial and ventricular muscle. In smooth muscle, they are involved in tension development for which process they provide part of the necessary calcium.
- Composition of the Calcium Channel

Initially, the L-type calcium channcl was purified from skeletal muscle. The purified complex contains four proteins (Figure 2): the $\alpha_{1}$ subunit [212,018 Daltons (D)], which contains the binding sites for all known $\mathrm{CaCBs}$ and the calciumconducting pore; the intracellularly located $\beta$ subunit $(57,868 \mathrm{D})$; the transmembrane $\gamma$ subunit $(25,058 \mathrm{D})$; and the $\alpha_{2} / \delta$ subunit, a disulfide-linked dimer of $125,018 \mathrm{D}$ [see Catterall et al. (1988), Hofmann et al. (1990), and references cited there]. Reconstitution of the purified complex into phospholipid bilayers results in functional calcium channcls that are reversibly blocked by CaCBs and are modulated by cAMP-dependent phosphorylation (Flockerzi et al. 1986, Hymel et al. 1988, Nunoki et al. 1989, Mundiña-Weilenmann et al. 1991). The primary sequences of these proteins have been deduced by cloning their corresponding cDNAs from rabbit skeletal muscle (Tanabe et al. 1987, Fllis et al. 1988, Ruth et al. 1989, Bosse et al. 1990, Jay et al. 1990). By using these cDNAs as probes, different $\alpha_{1}$ and $\beta$ subunits have been cloned from heart, smooth muscle, endocrine, and neuronal cells.

\section{- Subunits of the Calcium Channel}

The $\alpha_{1}$ Subunit

Complete cDNA clones of $\alpha_{1}$ subunits that direct the expression of functional calcium channels in Xenopus oocytes or cell culture cells have been isolated from skeletal, cardiac, smooth muscle, endocrine glands, and brain. The primary sequences of these cDNAs are homologous to one another and encode proteins of predicted molecular masses of 212-273 kD and homologies of $41 \%$ $70 \%$. Hydropathicity analysis of all $\alpha_{1}$ subunits predicts a transmembrane topology similar to that of other voltagedependent ion channels with four homologous repeats, each containing five hydrophobic putative transmembrane $\alpha$ helices and one amphipathic segment (S4) (Figure 2). By functional expression of chimeras of the skeletal 


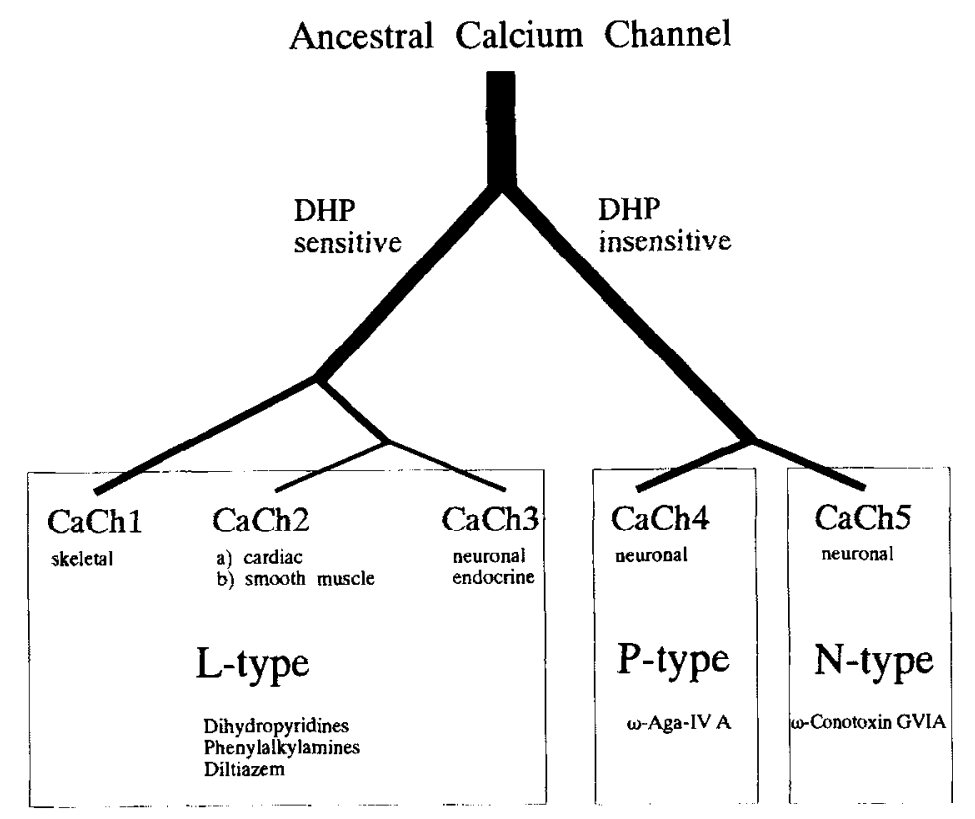

Figure 1. A putative developmental tree of the dihydropyridine-sensitive and -insensitive calcium channel genes. The numbering system of the calcium channel $\alpha_{1}$ subunit follows the order of publication of functional clones [see also Hofmann et al. (1993)]. The Snutch et al. (1990) nomenclature for brain calcium channels does not include the $\mathrm{CaCh} 1$ gene. The CaCh2, $\mathrm{CaCh} 3, \mathrm{CaCh} 4$, and $\mathrm{CaCh} 5$ genes correspond to Snutch genes $\mathrm{C}, \mathrm{D}, \mathrm{A}$, and $\mathrm{B}$, respectively.

and the cardiac muscle $\alpha_{1}$ subunit, specific properties of the calcium channel were assigned to distinct parts of the ion-conducting pore: repeat I determines the activation time of the chimeric channel, that is, slow activation upon membrane depolarization with the repeat from skeletal muscle and rapid activation with that from cardiac muscle (Tanabe et al. 1991); the putative cytoplasmic loop between repeats II and III determines the type of excitation-contraction coupling. The loop from the skeletal muscle calcium channel $\alpha_{1}$ subunit induces contraction in the absence of calcium influx, whereas the loop from the cardiac calcium channel $\alpha_{1}$ subunit induces contraction only in the presence of calcium influx (Tanabe et al. 1990). The "extracellular" loop between transmembrane helices 5 and 6 (SS1-SS2 region) is predicted to fold into the membrane, to form part of the pore of the channel (Guy and Conti 1990), and to take part in the control of ion selectivity (Heinemann et al. 1992). Photoaffinity labeling of skeletal muscle $\alpha_{1}$ subunit followed by limited proteolysis and immunoprecipitation indicates that the DHP-binding site is localized close to the SS1-SS2 region of repeat III (Striessnig et al. 1991,
Nakayama et al. 1991) and to a sequence following the IVS6 segment (Regulla et al. 1991), whereas the PAAbinding site has been located directly after the IVS6 segment (Striessnig et al. 1990) (Figure 2). Binding studies with radiolabeled DHPs demonstrate that the stably expressed $\alpha_{1}$ subunits from skeletal and smooth muscle alone contain the allosterically coupled binding sites for the known CaCBs (Kim et al. 1990, Bosse et al. 1992).

The so-far cloned cDNAs for the $\alpha_{1}$ subunits are encoded by five different genes (CaCh1-5) (Figure 1). The product of the $\mathrm{CaCh} 1$ gene occurs in skeletal muscle in two isoforms: a minor form $(-5 \%)$ of $212 \mathrm{kD}$ containing the complete amino acid sequence encoded by $\alpha_{1}$ mRNA, and a major form ( $\left.95 \%\right)$ of $190 \mathrm{kD}$ that is derived from the fulllength product by posttranslational proteolysis close to amino acid residue 1690 (De Jongh et al. 1991). Presumably, the shorter form is involved functionally at the triad in excitationcontraction coupling of the skeletal muscle. The short and the long forms are phosphorylated rapidly in vitro by cAMP-dependent protein kinase at Ser687 (Röhrkasten et al. 1988), which is located at the cytosolic loop between repeats II and III, and Ser-1854 (Rotman et al. 1992), which is present only in the larger untruncated form. The $\alpha_{1}$ subunits from cardiac ( $\mathrm{CaCh} 2 \mathrm{a})$ ( $\mathrm{Mi}$ kami et al. 1989) and smooth muscle (CaCh2b) (Biel et al. 1991) are splice products of the second gene ( $\mathrm{CaCh} 2)$, which is also expressed in other tissues. The homology of the deduced amino acid sequence of $\mathrm{CaCh} 2 \mathrm{a}$ to $\mathrm{CaCh} 2 \mathrm{~b}$ is $-95 \%$. A major difference between the cardiac and the smooth muscle $\alpha_{1}$ subunits is the different IVS 3 segment that results from alternative splicing of the primary transcript from the $\mathrm{CaCh} 2$ gene (Perez-Reyes et al. 1990). The two alternative splice variants $\mathrm{CaCh} 2 \mathrm{a}$ and $\mathrm{CaCh} 2 \mathrm{~b}$ have been expressed transiently and stably (Biel et al. 1991, Singer et al. 1991, Bosse et al. 1992). No major differences have been observed in basic electrophysiologic and pharmacologic properties of the two isoforms, including the amplitude of inward current, steady-state activation and inactivation, and DHP sensitivity (Welling et al. 1992b). However, Northern-blot and polymerase chain reaction (PCR) analyses show that both splice variants are differentially expressed in heart and smooth muscle (Biel et al. 1991) and during cardiac development (Diebold et al. 1992).

cDNA of the third gene ( $\mathrm{CaCh} 3)$ was isolated from neural and endocrine tissues and represents a neuroendocrinespecific L-type calcium channel (Williams et al. 1992a, Seino et al. 1992), whereas the gene products of the fourth and fifth genes ( $\mathrm{CaCh} 4$ and $\mathrm{CaCh} 5)$ have been found exclusively in neural tissues. Calcium channels transiently expressed from cRNA of $\mathrm{CaCh} 4$ induce high-voltage-activated calcium currents that are insensitive to nifedipine and $\omega$-conotoxin but are inhibited by a mixture of toxins from the funnel web spider that characterize this channel as a P-type calcium channel (Mori et al. 1991). The gene product of $\mathrm{CaCh} 5$ binds and is irreversibly blocked by picomolar concentrations of $\omega$-conotoxin, identifying the $\mathrm{CaCh} 5$ protein as a neuronal N-type calcium channel (Dubcl et al. 1992, Williams et al. 1992b).

\section{The $\alpha_{2} / \delta$ Subunit}

The skeletal muscle $\alpha_{2} / \delta$ subunit (CaA1) is a glycosylated membrane protein of 


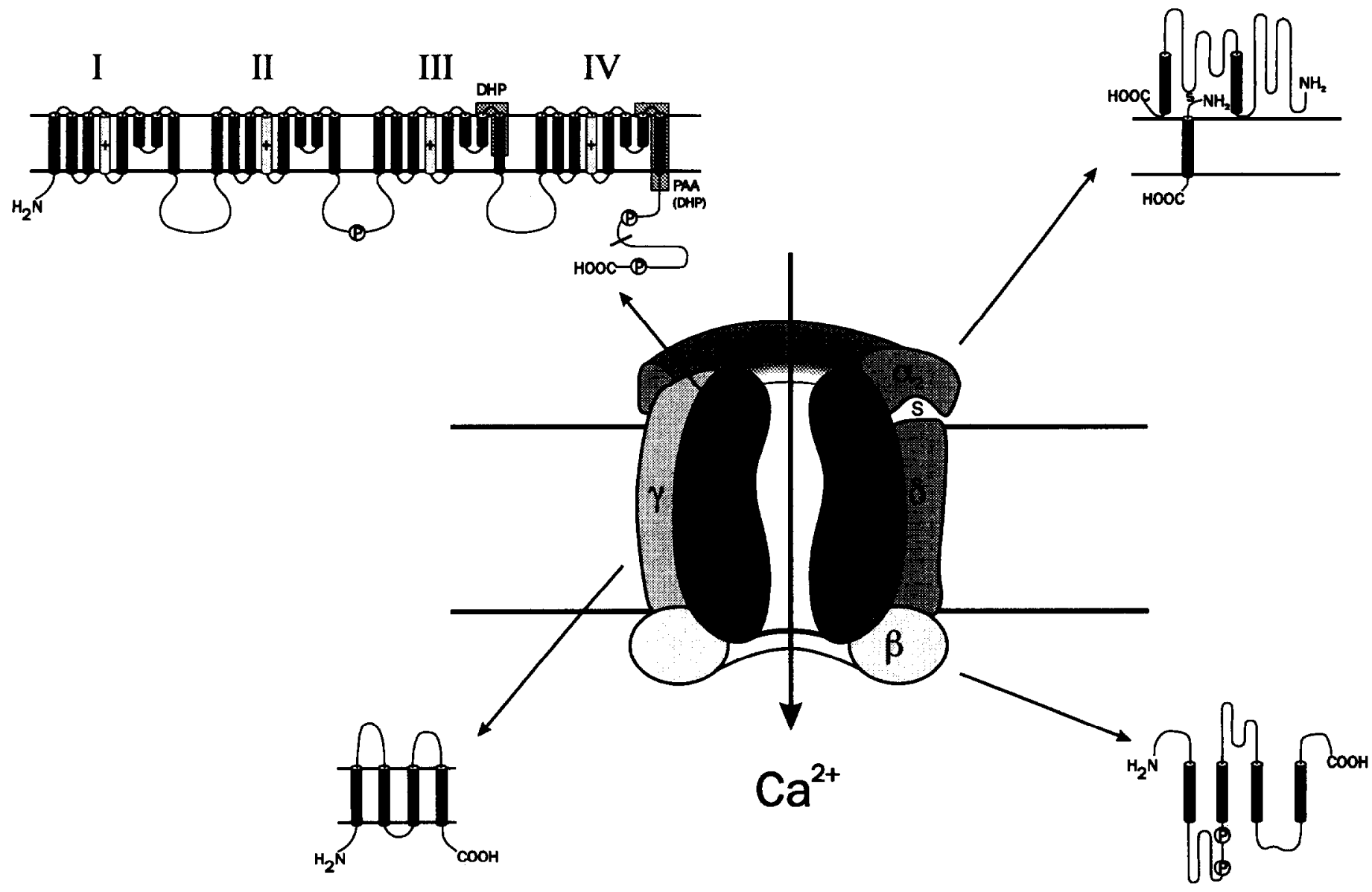

Figure 2. Proposed structure of the skeletal muscle calcium channel. The putative transmembrane configuration of individual subunits is taken from the hydropathicity analysis of the primary sequences: I, II, III, and IV are proposed repeats of calcium channel $\alpha_{1}$ subunit; + , proposed transmembrane amphipathic $\alpha$ helix and the proposed voltage-sensing helix of the channel, respectively; $\mathrm{P}$, sites phosphorylated in vitro by cAMP kinase; $\mathrm{s}$, disulfide bridge between the transmembrane $\delta$ and the extracellular located $\alpha_{2}$ subunit; the SS1-SS2 region is a suggested part of the channel pore containing part of the DHP-binding site; PAA, phenylalkylamine-binding site; and the dash at the carboxy-terminal part of $\alpha_{1}$ subunit indicates the area where the $\alpha_{1}$ subunit is processed posttranslationally. The extraccllular space is above the horizontal lines.

125,018 D (Ellis et al. 1988), which is apparently highly conserved in most tissues. In the skeletal muscle, the primary protein product of the $\alpha_{2} / \delta$ gene is processed posttranslationally by proteolysis resulting in an $\alpha_{2}$ protein containing amino acids 1-934 and a $\delta$ protein containing amino acids 935-1080 (De Jongh et al. 1990). The transmembrane $\delta$ subunit anchors the extracellular located $\alpha_{2}$ protein by disulfide bridges to the plasma membrane (Jay et al. 1991). Immunoblots (Norman et al. 1987) and Northern blots (Ellis et al. 1988, Biel et al. 1990) show that similar or identical $\alpha_{2} / \delta$ subunits exist in skeletal muscle, heart, brain, vascular, and intestinal smooth muscle. Two identical $\alpha_{2} / \delta \mathrm{cDNAs}$ have been isolated from rabbit skeletal muscle and human brain (Williams et al. $1992 a)$, whereas the $\alpha_{2} / \delta$ cDNA isolated from rat brain (Kim et al. 1992) predicts an identical $\delta$ protein and a splice variant of the processed $\alpha_{2}$ protein.

\section{The $\beta$ Subunit}

The skeletal $\beta$ subunit $(\mathrm{CaB} 1)$ is an intracellularly located membrane protein consisting of 524 amino acids (Ruth et al. 1989). Its deduced amino acid sequence contains stretches of heptad repeat structure that are characteristic for cytoskeletal proteins. Two other genes ( $\mathrm{CaB} 2$ and $\mathrm{CaB} 3$ ) encoding $\beta$ proteins different from the skeletal muscle $\beta$ subunit have been isolated from a car- diac cDNA library (Hullin et al. 1992). Their deduced amino acid sequences show an overall homology to $\mathrm{CaB} 1$ of $71 \%(\mathrm{CaB} 2)$ and $66.6 \%$ (CaB3). Differential splicing of the primary transcript of $\mathrm{CaB1}$ results in at least four isoforms: CaB1a-CaB1d (Ruth et al. 1989, Pragnell et al. 1991, Williams ct al. 1992a). $\mathrm{CaB1a}$ is expressed in skeletal muscle whereas the other isoforms are expressed in brain. Four different splice variants have been characterized for the $\mathrm{CaB} 2$ gene (CaB2a-CaB2d); $\mathrm{CaB} 2 \mathrm{a}$ and $\mathrm{CaB} 2 \mathrm{~b}$ have been isolated from a rabbit cardiac cDNA library whereas $\mathrm{CaB} 2 \mathrm{c}$ and $\mathrm{CaB2d}$ have been cloned from rabbit and rat brain libraries (Hullin et al. 1992, PerezReyes et al. 1992). Like the CaB1 gene, the $\mathrm{CaB} 2$ and $\mathrm{CaB} 3$ genes are tissuespecifically expressed with transcripts of $\mathrm{CaB} 2$ existing abundantly in heart and to a lower degree in aorta, trachea, and lung; whereas transcripts of $\mathrm{CaB} 3$ genes are expressed in brain and smooth-musclecontaining tissues such as aorta, trachea, and lung (Hullin et al. 1992). This suggests that the $\mathrm{CaB} 3$ gene product may be expressed predominantly in neuronal and smooth muscle cells. 


\section{The $\gamma$ Subunit}

The $\gamma$ subunit (CaG1) consists of 222 amino acids and is an integral membrane protein (Bosse et al. 1990, Jay et al. 1990). Its deduced amino acid sequence contains four putative transmembrane domains and two glycosylation sites that are located at the extracellular side. Northern and PCR analysis have not identified the presence of $\gamma$ subunit in other tissues, suggesting that this protein may be specific for skeletal muscle.

\section{- Functional Interaction of the Calcium Channel Subunits}

With the exception of the skeletal muscle $\alpha_{1}$ subunit, all other cDNAs of Figure 1 have been expressed singly or in combination with other subunits in Xenopus oocytes as functional ion channels. Transient expression in Xenopus oocytes of CaCh2a cRNA (Mikami et al. 1989) and CaCh2b cRNA (Biel et al. 1990) induces DHP-sensitive currents with electrophysiologic properties similar to those reported from cardiac and smooth muscle. Heterologous coexpression of the cardiac $\alpha_{1}$ subunit together with the skeletal muscle $\beta$ subunit and $\alpha_{2} / \delta$ subunit enhanced consistently the inward current to amplitudes $>1 \mu \mathrm{A} /$ oocyte (Singer et al. 1991). The $\alpha_{2} / \delta$ or $\beta$ subunits alone or the combination of both decreased the activation time of the barium current twofold (Singer et al. 1991, Wei et al. 1991). Oocytes containing all four subunits $\left(\alpha_{1}, \alpha_{2} / \delta, \beta\right.$, and $\left.\gamma\right)$ had fast-inactivating barium currents. The coexpression of the $\gamma$ subunit shifted the steady-state inactivation of $I_{\mathrm{Ba}}$ by 40 $\mathrm{mV}$ to negative membrane potentials (Singer et al. 1991). Under each condition, inward currents were increased several-fold by the calcium channel agonist BayK 8644. Homologous coexpression of the cardiac $\alpha_{1}$ subunit with the cardiac $\beta(\mathrm{CaB} 2)$ or the neuronal/smooth muscle $\beta$ subunit ( $\mathrm{CaB} 3$ ) with or without the $\alpha_{2} / \delta$ subunit results in an increase in the amplitude of $\mathrm{I}_{\mathrm{Ba}}$ as well as in an acceleration of channel activation (Hullin et al. 1992).

The three neuronal $\alpha_{1}$ subunit cDNAsthat is, the neuroendocrine L-type $\mathrm{CaCh} 3$ gene, the neuronal P-type $\mathrm{CaCh} 4$ gene, and the neuronal $\mathrm{N}$-type $\mathrm{CaCh} 5$ geneinduce barium currents only when coexpressed with the $\alpha_{2} / \delta$ and $\beta$ subunits
(Mori et al. 1991, Williams et al. 1992a and $b$ ). The increase in current occurred always in the presence of the $\beta$ subunit most likely by an increased number of plasmalemmal calcium channel molecules (see also below). These results suggest that the skeletal muscle $\beta$ subunit interacts with different $\alpha_{1}$ subunits by a common interaction site and mechanism. Similar effects of the subunits were obtained by stable coexpression of the skeletal muscle $\alpha_{1}$ and $\beta$ subunits in mouse fibroblasts ( $\mathrm{L}$ cells), which do not contain an endogenous calcium channel. The $\beta$ subunit decreased the activation time of the expressed channel $>50$-fold, and increased the number of DHP. binding sites twofold (Lacerda et al. 1991). In contrast to these results, it has been reported that coexpression of all four skeletal muscle subunits in $\mathrm{L}$ cells resulted in a decreased amplitude of the barium current and in a diminished response toward the calcium channel agonist BayK 8644 (Varadi et al. 1991). This phenomenon has not been observed with other L-type calcium channels expressed in Xenopus oocytes or CHO cells.

The smooth muscle $\alpha_{1}$ (CaCh2b) subunit induces barium currents in $\mathrm{CHO}$ cells that are identical to those of native smooth muscle: the single-channel conductance was $26 \mathrm{pSi}$ in the presence of 80 $\mathrm{mM} \mathrm{Ba}{ }^{2+}$, the open probability increased with membrane depolarization, and the voltage dependence of activation and inactivation was similar to that of the native smooth muscle channel (Bosse et al. 1992). Stable expression of the $\mathrm{CaCh} 2 \mathrm{~b}$ with the skeletal muscle $\beta$ gene (CaB1) increased in parallel the number of DHPbinding sites and the amplitude of whole cell barium current, suggesting that the amplitude of the inward current is directly related to the number of expressed $\alpha_{1}$ protein molecules (A. Welling et al., unpublished results). In addition, the coexpression of the $\beta$ subunit decreased the channel activation time twofold and shifted the voltage dependence of steadystate inactivation by $18 \mathrm{mV}$ to $-13 \mathrm{mV}$, without affecting the sensitivity toward the DHP agonist BayK 8644. The expression of the cardiac $\alpha_{1}$ subunit ( $\left.\mathrm{CaCh} 2 \mathrm{a}\right)$ in the same cells induces currents that are indistinguishable from that induced by the smooth muscle $\alpha_{1}$ subunit. The only difference noted was a faster activation of the cardiac channel. This electrophysiologic similarity is not surprising, since the primary sequence of both channels is 95\% identical (Biel et al. 1990).

\section{- Hormonal Modulation of the Cardiac and Smooth Muscle Calcium Channels}

Activation of the L-type calcium channel is voltage dependent, yet the response to changes in the membrane potential is modulated by hormones. The $\beta$-adrenergic receptor agonist isoproterenol increases the cardiac calcium current threeto sevenfold either by cAMP-dependent phosphorylation of the channel (Osterrieder et al. 1982, Hartzell ct al. 1991), by the activated $\alpha$ subunits of the trimeric GTP-binding protein $\mathrm{G}_{\mathrm{s}}$ (Yatani and Brown 1989 ), or by a combination of the activated $\alpha$ subunits of the trimeric GTPbinding protein $\mathrm{G}_{\mathrm{s}}$ and the active cAMP kinase (Cavalié et al. 1991) (Figure 3). The L-type calcium current of isolated tracheal smooth muscle cells is stimulated also by activation of the $\beta$ adrenergic receptor (Welling et al. 1992a). This $\beta$-receptor effect is mediated directly by a $G$ protein and not by cAMP-kinase activation. These results suggest that the $\mathrm{CaCh} 2$ gene product may be regulated in vivo by the $\alpha$ subunit of a $G$ protein and by cAMP-dependent phosphorylation. The primary sequences of cardiac and smooth muscle $\alpha_{1}$ subunits are almost identical and contain identical potential phosphorylation sites. It is therefore conceivable that the cAMP-dependent stimulation of the cardiac calcium channel depends not solely on the phosphorylation of the $\alpha_{1}$ subunit but also on the tissue-specific coexpression of other proteins, for example, the $\beta$ subunit. In support of this idea, it has been reported recently that cAMP increases barium currents in Xenopus oocytes expressing the cardiac $\alpha_{1}$ only in the presence of the skeletal muscle $\beta$ subunit (Klöckner et al. 1992). The reported inward currents were small and therefore did not exclude the possibility that the $\beta$ subunit stimulated in the presence of cAMP the endogenous Xenopus oocyte-specific calcium channel (Dascal et al. 1992). Whatever the correct interpretation of these results is, it is evident that the hormonal control of the cardiac calcium channel may be exerted not through the $\alpha_{1}$ subunit alone but by tissue-specific expression of various $\beta$ subunits. The deduced amino acid sequence of the skeletal muscle $\beta$ subunit 


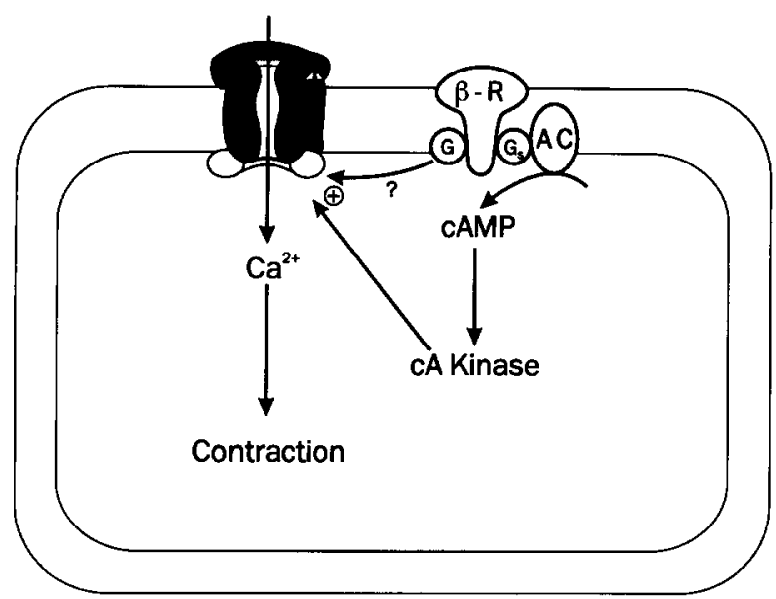

Figure 3. Suggested regulation of the cardiac calcium channel. Note that the cardiac calcium channel does not contain a $\gamma$ subunit. $\beta-R, \beta$-adrenergic receptor; $G$, trimeric GTP-binding protein; and AC, adenylyl cyclase.

( $\mathrm{CaB} 1$ ) contains several phosphorylation sites. Two of these sites, Ser-182 and Thr-205, are phosphorylated in vitro by cAMP-dependent protein kinase (Ruth et al. 1989, De Jongh et al. 1989). The equivalent to Thr-205 is conserved in the "cardiac" $\beta$ subunit (Thr-165 in $\mathrm{CaB} 2 \mathrm{a}$ and $\mathrm{Thr}-191 \mathrm{in} \mathrm{CaB} 2 \mathrm{~b}$ ) but is not present in the "smooth muscle" $\beta$ subunit CaB3. The sequence following this potential phosphorylation site is highly variable and determines several splice variants (Hullin et al. 1992). This variable region may be responsible for the tissue-specific regulation of the L-type calcium currents by hormones and neurotransmitters.

\section{- Conclusion}

High-voltage-activated calcium channels are oligomeric complexes of four different subunits: $\alpha_{1}, \alpha_{2} / \delta, \beta$, and $\gamma$. So far, five different genes encoding $\alpha_{1}$ subunits and three distinct genes encoding $\beta$ subunits have been isolated from various tissues. The specific electrophysiologic and pharmacologic characteristics of calcium currents in different cells result from the expression of tissue-specific subunits of the calcium channel leading to differences in functional interaction. This genetic polymorphism explains also the different regulatory mechanisms and possibly offers a chance for a therapy with more specific drugs than those on hand in the future.

\section{- Acknowledgments}

The results obtained in the authors' laboratory were supported by grants from the Deutsche Forschungsgemeinschaft and the Fond der Chemie.

\section{References}

Biel M, Ruth P, Bosse E, et al.: 1990. Primary structure and functional expression of a high voltage activated calcium channel from rabbit lung. FEBS Lett 269:409-412.

Biel M, Hullin R, Freundner S, et al.: 1991. Tissue-specific expression of high-voltageactivated dihydropyridine-sensitive L-type calcium channels. Eur J Biochem 200:8188.

Bosse E, Regulla S, Biel M, et al.: 1990. The cDNA and deduced amino acid sequence of the $\gamma$ subunit of the L-type calcium channel from rabbit skeletal muscle. FEBS Lett 267:153-156.

Bosse E, Bottlender R, Kleppisch T, et al.: 1992. Stable and functional expression of the calcium channel $\alpha_{1}$ subunit from smooth muscle in somatic cell lines. EMBO J 11:2033-2038.

Catterall WA, Seagar MJ, Takahashi M: 1988. Molecular properties of dihydropyridine-sensitive calcium channels in skeletal muscle. J Biol Chem 263:3533-3538.

Cavalié A, Allen TJA, Trautwein W: 1991. Role of the GTP-binding protein $\mathrm{G}_{\mathrm{s}}$ in the $\beta$ adrenergic modulation of cardiac $\mathrm{Ca}$ channels. Pflugers Arch 419:433-443.

Dascal N, Lotan I, Karni E, Gigi A: 1992. Calcium channel currents in Xenopus oocytes injected with rat skeletal muscle RNA. J Physiol (Lond) 450:469-490.

De Jongh KS, Merrick DK, Catterall WA: 1989. Subunits of purified calcium channels: a 212-kDa form of $\alpha_{1}$ and partial amino acid sequence of a phosphorylation site of an independent $\beta$ subunit. Proc Natl Acad Sci USA 86:8585-8589.

De Jongh KS, Warner C, Catterall WA:
1990. Subunits of purified calcium channels: $\alpha_{2}$ and $\delta$ are encoded by the same gene. J Biol Chem 265:14,738-14,741.

De Jongh KS, Warner C, Colvin AA, Catterall WA: 1991. Characterization of the two size forms of the $\alpha_{1}$ subunit of skeletal muscle L-type calcium channels. Proc Natl Acad Sci USA 88:10,778-10,782.

Diebold RJ, Koch WJ, Ellinor PT, et al.: 1992. Mutually exclusive exon splicing of the cardiac calcium channel $\alpha_{1}$ subunit gene generates developmentally regulated isoforms in the rat heart. Proc Natl Acad Sci USA 89:1497-1501.

Dubel SJ, Starr TVB, Hell J, et al.: 1992. Molecular cloning of the $\alpha-1$ subunit of an $\omega$-conotoxin-sensitive calcium channel. Proc Natl Acad Sci USA 89:5058-5062.

Ellis SB, Williams ME, Ways NR, ct al.: 1988. Sequence and expression of mRNAs encoding the $\alpha_{1}$ and $\alpha_{2}$ subunits of a DHPsensitive calcium channel. Science 241:16611664.

Fleckenstein A, Kammermeier H, Döring HJ, Freund HJ: 1967. Zum Wirkungsmechanismus neuartiger Koronardilatatoren mit gleichzeitig Sauerstoff-einsparenden MyokardEffekten: Prenylamin und Iproveratil. Z Kreislaufforsch 56:716-744.

Flockerzi V, Oeken HJ, Hofmann F, Pelzer D, Cavalié A, Trautwein W: 1986. Purified dihydropyridine-binding site from skeletal muscle t-tubules is a functional calcium channel. Nature 323:66-68.

Glossmann H, Striessnig J: 1988. Calcium channels. Vitam Horm 44:155-328.

Guy HR, Conti F: 1990. Pursuing the structure and function of voltage-gated channels. Trends Neurol Sci 13:201-206.

Hartzell HC, Mery P-F, Fischmeister R, Szabo G: 1991. Sympathetic regulation of cardiac calcium current is due exclusively to cAMPdependent phosphorylation. Nature 351: 573-576.

Heinemann SH, Terlau H, Stühmer W, Imoto K, Numa S: 1992. Calcium channel characteristics conferred on the sodium channel by single mutations. Nature 356:441 443 .

Hofmann F, Flockerzi V, Nastainczyk W, Ruth P, Schneider T: 1990 . The molecular structure and regulation of muscular calcium channels. Curr Top Cell Regul 31:223239.

Hofmann F, Biel M, Hullin R, Bosse E, Flockerzi V: 1993. High voltage activated calcium channels. Handb Pharmacol (in press).

Hullin R, Singer-Lahat D, Freichel $\mathbf{M}$, et al.: 1992. Calcium channel $\beta$ subunit heterogeneity: functional expression of cloned cDNA from heart, aorta and brain. EMBO J 11:885-890.

Hymel L, Striessnig J, Glossmann H, Schin- 
dler H: 1988. Purified skeletal muscle 1,4dihydropyridine receptor forms phosphorylation-dependent oligomeric calcium channels in planar bilayers. Proc Natl Acad Sci USA 85:4290-4294.

Jay SD, Ellis SB, McCue AF, et al.: 1990. Primary structure of the $\gamma$ subunit of the DHP-sensitive calcium channel from skeletal muscle. Science 248:490-492.

Jay SD, Sharp AH, Kahl StD, Vedvick TS, Harpold MM, Campbell KP: 1991. Structural characterization of the dihydropyridinesensitive calcium channel $\alpha_{2}$-subunit and the associated $\delta$ peptides. J Biol Chem 266:3287-3293.

Kim HS, Wei X, Ruth P, et al.: 1990. Studies on the structural requirements for the activity of the skeletal muscle dihydropyridine receptor/slow $\mathrm{Ca}^{2+}$ channel. J Biol Chem 265:11,858-11,863.

Kim HL, Kim H, Lee P, King RG, Chin HR: 1992. Rat brain expresses an alternatively spliced form of the dihydropyridinesensitive L-type calcium channel alpha-2 subunit. Proc Natl Acad Sci USA 89:32513255.

Klöckner U, Itagaki K, Bodi I, Schwartz A: 1992. $\beta$-Subunit expression is required for cAMP-dependent increase of cloned cardiac and vascular calcium channel currents. Pflugers Arch 420:413-415.

Lacerda AE, Kim HS, Ruth P, et al.: 1991. Normalization of current kinetics by interaction between the $\alpha_{1}$ and $\beta$ subunits of the skeletal muscle dihydropyridine-sensitive $\mathrm{Ca}^{2+}$ channel. Nature 352:527-530.

Mikami A, Imoto K, Tanabe T, et al.: 1989. Primary structure and functional expression of the cardiac dihydropyridinesensitive calcium channel. Nature 340:230233.

Mintz IM, Venema VJ, Swiderek KM, Lee TD, Bean BP, Adams ME: 1992. P-type calcium channels blocked by the spider toxin $\omega$-AgaIVA. Nature 355:827-830.

Mori Y, Friedrich T, Kim MS, et al.: 1991. Primary structure and functional expression from complementary DNA of a brain calcium channel. Nature 350:398-402.

Mundiña-Weilenmann $\mathrm{C}$, Chang $\mathrm{ChF}$, Gutierrez LM, Hosey MM: 1991. Demonstration of the phosphorylation of dihydropyridinesensitive calcium channels in chick skeletal muscle and the resultant activation of the channels after reconstitution. J Biol Chem 266:4067-4073.

Nakayama H, Taki $M$, Striessnig J, Glossmann H, Catterall WA, Kanaoka Y: 1991. Identification of 1,4-dihydropyridine binding regions within the $\alpha_{1}$ subunit of skeletal muscle $\mathrm{Ca}^{2+}$ channels by photoaffinity labeling with diazipine. Proc Natl Acad Sci USA 88:9203-9207.
Norman RI, Burgess AJ, Allen E, Harrison TM: 1987. Monoclonal antibodies against the 1,4-dihydropyridine receptor associated with voltage-sensitive $\mathrm{Ca}^{2+}$ channels detect similar polypeptides from a variety of tissues and species. FEBS Lett 212:127-132.

Nunoki K, Florio V, Catterall WA: 1989. Activation of purified calcium channels by stoichiometric protein phosphorylation. Proc Natl Acad Sci USA 86:6816-6820.

Osterrieder W, Brum G, Hescheler J, Trautwein W, Flockerzi V, Hofmann F: 1982. Injection of subunits of cyclic AMPdependent protein kinase into cardiac myocytes modulates $\mathrm{Ca}^{2+}$ current. Nature 298:576-578.

Perez-Reyes E, Wei X, Castellano A, Birnbaumer L: 1990. Molecular diversity of L-type calcium channel: evidence for alternative splicing of the transcripts of three non-allelic genes. J Biol Chem 265:20,43020,436.

Perez-Reyes E, Castellano A, Kim HS, et al.: 1992. Cloning and expression of cardiac/ brain $\beta$ subunit of the L-type calcium channel. J Biol Chem 267:1792-1797.

Pragnell M, Sakamoto J, Jay SD, Campbell KP: 1991. Cloning and tissue-specific expression of the brain calcium channel $\beta$-subunit. FEBS Lett 291:253-258.

Regulla S, Schncider T, Nastainczyk W, Meyer HE, Hofmann F: 1991. Identification of the site of interaction of the dihydropyridine channel blockers nitrendipine and azidopine with the calcium channel $\alpha_{1}$ subunit. EMBO J 10:45-49.

Röhrkasten A, Meyer HE, Nastainczyk W, Sieber M, Hofmann F: 1988. cAMP. dependent protein kinase rapidly phosphorylates serine- 687 of the skeletal muscle receptor for calcium channel blockers. J Biol Chem 263:15,325-15,329.

Rotman EI, De Jongh KS, Florio V, Lai Y, Catterall WA: 1992. Specific phosphorylation of a COOH-terminal site on the fulllength form of the $\alpha_{1}$ subunit of the skeletal muscle calcium channel by cAMP-dependent protein kinase. J Biol Chem 267:16,10016,105 .

Ruth P, Röhrkasten A, Biel M, et al.: 1989. Primary structure of the $\beta$ subunit of the DHP-sensitive calcium channel from skeletal muscle. Science 245:1115-1118.

Seino S, Chen L, Seino M, et al.: 1992. Cloning of the $\alpha_{1}$ subunit of a voltage-dependent calcium channel expressed in pancreatic $\beta$ cells. Proc Natl Acad Sci USA 89:584-588.

Singer D, Biel M, Lotan I, Flockerzi V, Hofmann F, Dascal N: 1991. The roles of the subunits in the function of the calcium channel. Science 253:1553-1557.

Snutch TP, Leonard JP, Gilbert MM, Lester HA, Davidson N: 1990 . Rat brain expresses a heterogeneous family of calcium channels. Proc Natl Acad Sci USA 87:3391-3395.

Striessnig J, Glossmann H, Catterall WA: 1990. Identification of a phenylalkylamine binding region within the $\alpha_{1}$ subunit of skeletal muscle $\mathrm{Ca}^{2+}$ channels. Proc Natl Acad Sci USA 87:9108-9112.

Striessnig J, Murphy BJ, Catterall WA: 1991. Dihydropyridine receptor of L-type $\mathrm{Ca}^{2+}$ channels: identification of binding domains for $\left[{ }^{3} \mathrm{H}\right](+)-P N 200-110$ and $\left[{ }^{3} \mathrm{H}\right]$ azidopine within the $\alpha_{1}$ subunit. Proc Natl Acad Sci USA 88:10,769-10,773.

Tanabe T, Takeshima H, Mikami A, et al.: 1987. Primary structure of the receptor for calcium channel blockers from skeletal muscle. Nature 328:313-318.

Tanabe T, Beam KG, Adams BA, Niidome T, Numa S: 1990 . Regions of the skeletal muscle dihydropyridine receptor critical for excitation-contraction coupling. Nature 346:567-569.

Tanabe T, Adams BA, Numa S, Beam KG: 1991. Repeat I of the dihydropyridine receptor is critical in determining calcium channel activation kinetics. Nature 352:800 803.

Tsien RW, Ellinor PT, Horne WA: 1991. Molecular diversity of voltage-dependent $\mathrm{Ca}^{2+}$ channels. Trends Pharmacol Sci 12:349354.

Varadi G, Lory P, Schultz D, Varadi M, Schwartz A: 1991. Acceleration of activation and inactivation by the $\beta$ subunit of the skeletal muscle calcium channel. Nature 352:159-162.

Wei X, Perez-Reyes E, Lacerda AE, Schuster G, Brown AM, Birnbaumer L: 1991. Heterologous regulation of the cardiac $\mathrm{Ca}^{2+}$ channel $\alpha_{1}$ subunit by skeletal muscle $\beta$ and $\gamma$ subunits. J Biol Chem 266:21,943-21,947.

Welling A, Felbel J, Peper K, Hofmann F: 1992a. Hormonal regulation of calcium current in freshly isolated airway smooth muscle cells. Am J Physiol 262:L351-L359.

Welling A, Bosse E, Ruth P, Bottlender R, Flockerzi V, Hofmann F: 1992b. Expression and regulation of cardiac and smooth muscle calcium channels. J Pharmacol 58(Suppl 2):258p-262p.

Williams ME, Feldman DH, McCue AF, et al.: 1992a. Structure and functional expression of $\alpha_{1}, \alpha_{2}$, and $\beta$ subunits of a novel human neuronal calcium channel subtype. Neuron 8:71-84.

Williams ME, Brust PF, Feldman DH, et al.: 1992b. Structure and functional expression of an $\omega$-conotoxin-sensitive human $\mathrm{N}$-type calcium channel. Science 257:389-395.

Yatani A, Brown AM: 1989. Rapid $\beta$ adrenergic modulation of cardiac calcium channel currents by a fast $G$ protein pathway. Science 245:71-74.

TCM 